\title{
ASSOCIATION BETWEEN SERUM RESISTIN LEVEL AND PERIODONTAL CONDITION CHANGE AMONG ELDERLY PEOPLE \\ Hiroshi Ogawa ${ }^{1 a^{*}}$, Teerasak Damrongrungruang ${ }^{2 b}$, Reiko Furugen ${ }^{3 c}$, Hideaki Hayashida ${ }^{3 \mathrm{~d}}$, Toshiyuki Saito ${ }^{3 e}$,

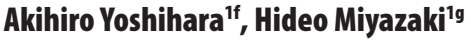

'Division of Preventive Dentistry, Department of Oral Health Science, Graduate School of Medical and Dental Sciences, Niigata University, Niigata, Japan ${ }^{2}$ Department of Oral Diagnosis, Faculty of Dentistry, Khon Kaen University, Muang, Khon Kaen, Thailand

${ }^{3}$ Department of Oral Health, Unit of Social Medicine, Graduate School of Biomedical Sciences, Nagasaki University, Nagasaki, Japan

${ }^{a} D D S$, MDSC, PhD, Associate Professor

${ }^{b} D D S$, PhD, Associate Professor

'DDS, PhD, Assistant Professor

dDDS, PhD, Lecturer

e,f,gDDS, PhD, Professor

ABSTRACT

DOI: 10.25241/stomaeduj.2018.5(1).art.2

Aim: This study aimed to compare periodontal condition in four years of Japanese elderly between high and low serum resistin levels.

Materials and methods: One hundred and thirty-two dentate community-dwelling participants enrolled in this cohort study. At baseline, blood sample were drawn for serum resistin and other adipokines/cytokines measurements. The participants were then divided into 2 groups; low resistin (LR, resistin $<5.3 \mathrm{ng} / \mathrm{mL})$ group $(\mathrm{n}=84)$ and high resistin ( $H R$, resistin $\geq 5.3 \mathrm{ng} / \mathrm{mL})$ group $(n=48)$. At baseline and after four years, all participants were subjected to periodontal examination (assessment pocket depth; PD and bleeding on probing; BOP). Annual general/oral health questionnaires were also performed. Intergroup comparisons of periodontal parameters and categorical variables were accomplished by t-test and Chi-square test, respectively. Association between baseline serum resistin level and periodontal condition alteration after four years in each group were analyzed by a multiple linear regression analysis.

Results: At baseline, HR group had more sites with PD $\geq 4 \mathrm{~mm}$ concomitant BOP than those of LR group (5.8 \pm 9.0 vs. $2.8 \pm 4.8$ sites). High serum resistin concentration and number of tooth loss markedly associated with reduction of sites with PD $\geq 4 \mathrm{~mm}$ and $\mathrm{PD} \geq 4 \mathrm{~mm}$ concomitant BOP.

Conclusion: High serum resistin level might negatively be associated to periodontal disease progression.

Keywords: adipokine, elderly, inflammation, periodontitis, resistin.

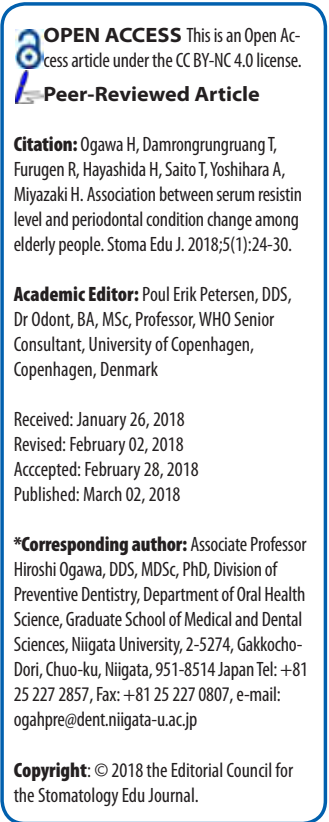

\section{Introduction}

Adipose tissue, in current view, is not only an inert organ for energy storage, but it is able to mediate signals to play important roles in a number of physiological responses, for instance activation of secretory process from endocrine and reproductive system, modulation of bone metabolism and controlling inflammatory processes [1]. It is well established knowledge in recent years that increase in metabolic overload relates to more frequent obesity and is closely associated with higher systemic inflammations [1]. Adipocytes produce a number of adipokine such as adiponectin, resistin and leptin as well as cytokine including tumor necrosis factor alpha (TNF-a) and interleukin-6 (IL6). These factors play a pivotal role in inflammation and immune reaction $[1,2]$. TNF- $a$ and IL-6, two major inflammatory cytokines, were shown to overexpress in adipose tissue of obese mice and human, which clearly showed the link between obesity, diabetes and chronic inflammation [3-5]. Additionally, soluble molecules from adipocytes played a complex interaction with the immune cells [6]. Adiponectin, one of a well-studied adipokines, acts as an anti-inflammatory factor due to it inhibited TNF-a-induced adhesion molecule expression [7] and induced anti-inflammatory cytokine IL-10 and IL1R in human leukocytes [8]. Furthermore, its level is slightly decreased in periodontitis [9].

Resistin is an 144-amino-acid adipokine which was previously said to be predominantly expressed in adipocytes [10-11]. However, recent evidence demonstrated that resistin expressed mainly from macrophages and bone marrow cells and is linked to the inflammatory cascade [12] as well as an immune response [1]. It was found that lipopolysaccharides from pathogenic bacteria in human volunteers stimulated secretion of circulating serum resistin levels [13]. On the contrary, the NF-kB inhibitor could counteract the proinflammatory properties of resistin, thus demonstrating the interplay of the NF-KB in the resistin-induced modulation of the inflammatory cascades [14]. Previous obesity and insulin resistance and glucose-lowering therapies reduced resistin gene expression [15]. Periodontitis, a multifactor chronic inflammatory disease caused mainly by intraoral pathogens, is strongly linked to the immune system $[16,17]$. Obesity has also been suggested to be linked to periodontitis in the way that periodontitis was exacerbated by some reports found that resistin was positively correlated with 
conditions associated with obesity e.g. insulin resistance [18]. It was suggested that increased serum resistin levels were correlated with developed periodontitis in elderly Japanese [9]. Furthermore, non-surgical periodontal treatment slightly decreased circulating resistin level [19]. Bleeding on probing is generally known parameter that directly reflects inflammatory condition and is considered as a predictor of periodontal disease progression in elderly [20]. We hypothesized that serum resistin level but not adiponectin might relate to the progression of periodontitis by the changing of bleeding on probing sites. However, this hypothesis has never been proved yet.

Even several lines of evidence support the higher level of serum resistin in periodontitis patients, but recent reports concluded that there were almost no differences of serum resistin levels between normal VS periodontitis patients [21-22]. Whether they influence the alteration of periodontal conditions in a long-term period still has not yet been reported. The aim of the present study was to investigate whether serum resistin levels associate to the long term periodontal condition alteration.

\section{Materials and Methods}

\subsection{Study design and participants}

The present cohort, parallel design study was performed as part of the Niigata elderly study. A total of 161 Japanese elderly residing in Niigata, Japan and aged 76 at baseline participated during the entire period of the present study. Our inclusion criteria were healthy individuals and the exclusion criteria included any severe systemic disease(s) or disability condition(s). Ethical approval was obtained from the Niigata University Review Board (21-R13-09-08) and all procedures were undergone in the Niigata University Hospital. After the participants signed the informed consent, they were asked to answer the general/oral health questionnaires. The diagnosis of periodontitis was based on the criteria as designed by the American Academy of Periodontology in 1999 [23].

\subsection{Periodontal Examination}

Four trained dentists were involved in this study and were calibrated for periodontal examination until the kappa value for probing pocket depth $\geq 0.8$ was reached. All remaining teeth were subjected to 6 sites/ tooth examination. The measurements of the probing pocket depth (PD) were based on nearest millimeter intervals and all sites with bleeding on probing (BOP) were also recorded. Periodontal examinations were conducted at baseline and at the 4th-year follow-up examinations. Analyses were performed by another dentist who was not involved in the patient clinical outcome measurements.

\subsection{Biological measurement}

Blood samples were taken and kept at $-70^{\circ} \mathrm{C}$ until subsequent measurements of $\mathrm{HbA} 1 \mathrm{c}$, adiponectin, resistin, IL-6 and TNF-a by KHP0041, KHP0051, KHC0064 and KHC3014 ELISA kits (Biosource International Inc., CA, USA), respectively. Before measurements, the validation of the method was performed by fabrication of standard curve following the instruction from
I Table 1. Basic characteristics, HbA1c and periodontal characteristics of the study participants at baseline

\begin{tabular}{|c|c|c|c|}
\hline \multirow[b]{2}{*}{ Characteristics } & \multirow[b]{2}{*}{ Overall } & \multicolumn{2}{|r|}{ Resistin } \\
\hline & & $\begin{array}{r}\text { LR (<5.3 ng/ } \\
\mathrm{mL}) \mathrm{N}=84\end{array}$ & $\begin{array}{r}\mathrm{HR}(\geq 5.3 \mathrm{ng} / \\
\mathrm{mL}) \mathrm{N}=48\end{array}$ \\
\hline \multicolumn{4}{|c|}{ General characteristics } \\
\hline Male/female & $64 / 68$ & $40 / 44$ & $24 / 24$ \\
\hline $\begin{array}{l}\text { Number of } \\
\text { present teeth }\end{array}$ & $20.53 \pm 5.87$ & $20.36 \pm 5.67$ & $20.83 \pm 6.21$ \\
\hline $\begin{array}{r}\text { Alcoohol } \\
\text { drinking (\%) }\end{array}$ & 64.12 & 64.29 & 63.83 \\
\hline Smocking (\%) & 44.70 & 46.43 & 41.67 \\
\hline $\mathrm{HbA} 1 \mathrm{c}(\%)$ & $5.22 \pm 0.70$ & $5.27 \pm 0.81$ & $5.13 \pm 0.46$ \\
\hline $\operatorname{BMI}\left(\mathrm{kg} / \mathrm{m}^{2}\right)$ & $22.69 \pm 2.62$ & $22.75 \pm 2.69$ & $22.59 \pm 2.51$ \\
\hline \multicolumn{4}{|c|}{ Serological parameters } \\
\hline $\begin{array}{r}\text { Adiponectin } \\
(\mu \mathrm{g} / \mathrm{mL})\end{array}$ & $11.09 \pm 4.82$ & $11.17 \pm 4.80$ & $10.97 \pm 4.88$ \\
\hline TNF- $a(p g / m L)$ & $0.97 \pm 1.59$ & $0.94 \pm 1.80$ & $1.03 \pm 1.14$ \\
\hline IL-6 (pg/mL) & $0.75 \pm 1.89$ & $0.75 \pm 1.97$ & $0.76 \pm 1.75$ \\
\hline
\end{tabular}

the manufacturer. All serological parameters were measured once at the baseline period.

\subsection{Health Status Interview}

At baseline and at 4th-year, the participants were asked to participate in an annual health examination which includes a general health check-up and the oral health questionnaires. We included the questions about receiving dental (including periodontal) treatment and recent tooth loss in the questionnaires as well in order to evaluate the oral health maintenance manner of subjects.

\subsection{Statistical Analysis}

For continuous variables, the t-test was used for intergroup comparisons. Categorical variables comparisons between groups were conducted using Chi-square test. For association between baseline serum resistin level and periodontal condition after 4 years, multiple linear regression models were used to predict changes of sites with $\mathrm{PD} \geq 4 \mathrm{~mm}$ and sites with $\mathrm{PD} \geq 4 \mathrm{~mm}$ concomitant BOP by the influence of serum resistin, adiponectin, IL-6, TNF-a level and number of tooth loss. The P-value $<0.05$ was determined as statistically significant. All statistical analyses were conducted using the STATA software package (Stata Corp., www.stata.com).

\section{Results}

A total of 132 participants (64 male and 68 female) were included in the present study because 29 participants were totally edentulous individuals. Almost all participants were non-diabetic because the average $\mathrm{HbA1c}$ at baseline was $5.22 \pm 0.70 \%$. Only 5 participants $(3.8 \%)$ had $\mathrm{HbA} 1 \mathrm{c}$ level more than $6.7 \%$ (a cut-off point of increased risk of hypoglycemia according to the Japanese Diabetes Diagnostic Criteria (1999) [24]. Of these, 84 participants were classified into a low resistin group (LR), (with an 
individual having a serum resistin level $<5.3 \mathrm{ng} / \mathrm{mL}$, and 48 participants were in a high resistin group (HR), or who had serum resistin from $5.3 \mathrm{ng} / \mathrm{mL}$. This categorization was according to a previous study [9].

Table 1 shows the characteristic of the participants at baseline. Based on general data, $44.7 \%$ (59 out of 132) of participants were smokers. With respect to the drinking habit, one participant who was in the $\mathrm{HR}$ group refused to answer the questionnaire so we excluded this participant in the analysis of the drinking habit and we found that $64.1 \%$ (84 out of 131) of participants drank alcohol. There was no difference regarding the number of drinkers or smokers between the groups. The distribution of serum resistin ranged from 1.2 to $17.9 \mathrm{ng} / \mathrm{mL}$ with an average of $5.38 \pm 3.24$ $\mathrm{ng} / \mathrm{mL}$. The average BMI of participants in the present study were in the normal weight range based on the WHO classification for Asians [25]. Six participants (5 in LR and 1 in HR group, data not shown) were classified as obese (BMI $\geq 27.5$ ). With respect to the adipokine/ cytokines data at baseline, there were no differences between the groups in all these parameters (Table 1). Intergroup comparisons of periodontal parameters are shown in Table 2. At baseline, the HR group had sites with $P D \geq 4 \mathrm{~mm}$, and sites with $\mathrm{PD} \geq 4 \mathrm{~mm}$ concomitant BOP 1.58. This was 2 times higher than those of the LR group, respectively.

There were statistically significant differences at $p=$ 0.026 and 0.016 , respectively. Interestingly, after 4 years all these parameters were improved in all participants. Alteration of above parameters were markedly detected in the HR group for both sites with $P D \geq 4 \mathrm{~mm}$ and sites with $\mathrm{PD} \geq 4 \mathrm{~mm}$ concomitant BOP which were reduced by $54.2 \%$ and $92.5 \%$ after 4 years, respectively while in the LR group, these parameters decreased only by $28.3 \%$ and $87.2 \%$, respectively from baseline. No significant difference was found between groups regarding $P D \geq$ $6 \mathrm{~mm}$, and PD $\geq 6 \mathrm{~mm}$ concomitant BOP. The average number of tooth loss was only 1.1 teeth $(5.0 \%$ loss from baseline) in the LR group, and 1.62 teeth (7.8\% loss from baseline) in the HR group.

Multiple linear regression analyses (Table 3 and 4) were performed using alteration in the number of sites with $\mathrm{PD} \geq 4 \mathrm{~mm}$, and these sites concomitant BOP during 4 years as a dependent variable, and all adipokines/ cytokines level at baseline as well as the number of tooth loss in 4 years as independent variables. It was found that serum resistin levels had a significant contribution effect on the improvement of sites with PD $\geq 4 \mathrm{~mm}$ (correlation coefficient $=-0.49 ; \mathrm{p}=0.080$ ), and also inflammation shown by the reduction of sites with $\mathrm{PD} \geq 4 \mathrm{~mm}$ concomitant BOP (correlation coefficient $=-0.41, p=0.009$ ). The other cytokines and adipokine, however, appeared to have no such relationship. Additionally, the number of teeth lost during the 4-year period also had a significantly positive effect on the reduction of sites with $\mathrm{PD} \geq 4 \mathrm{~mm}$ and sites with $\mathrm{PD} \geq$ $4 \mathrm{~mm}$ concomitant BOP (correlation coefficient $=-2.48$; $p=0.000$ and correlation coefficient $=-0.78 ; p=0.001$, respectively).

Most of participants received periodontal treatment during the study period. Table 5 shows the numbers of participants who received scaling and scaling with root planning which were 109 (82.6\%) and 56 (42.4\%)
Table 2. Comparison of periodontal conditions between low (LR) and high (HR) serum resistin

\begin{tabular}{|c|c|c|c|}
\hline \multirow[b]{2}{*}{ Characteristics } & \multicolumn{2}{|c|}{ Resistin } & \multirow[b]{2}{*}{$p$ value } \\
\hline & $\begin{array}{r}\mathrm{LR}(<5.3 \mathrm{ng} / \\
\mathrm{mL}) \mathrm{N}=84\end{array}$ & $\begin{array}{r}\mathrm{HR}(\geq 5.3 \mathrm{ng} / \\
\mathrm{mL}) \mathrm{N}=48\end{array}$ & \\
\hline \multicolumn{4}{|c|}{ Periodontal conditions (Baseline) } \\
\hline $\begin{array}{r}\text { Sites with } P D \geq \\
4 \mathrm{~mm}\end{array}$ & $9.91 \pm 11.98$ & $15.62 \pm 17.02$ & 0.026 \\
\hline $\begin{array}{r}\text { Sites with PD } \geq \\
6 \mathrm{~mm}\end{array}$ & $1.69 \pm 3.11$ & $2.75 \pm 5.17$ & 0.144 \\
\hline $\begin{array}{r}\text { Sites with } \mathrm{PD} \geq 4 \\
\mathrm{~mm} \text { concomitant } \\
\text { BOP }\end{array}$ & $2.82 \pm 4.84$ & $5.75 \pm 8.97$ & 0.016 \\
\hline $\begin{array}{r}\text { Sites with } \mathrm{PD} \geq 6 \\
\mathrm{~mm} \text { concomitant } \\
\text { BOP }\end{array}$ & $0.60 \pm 1.69$ & $1.02 \pm 2.07$ & 0.216 \\
\hline $\begin{array}{l}\text { Number of } \\
\text { present teeth }\end{array}$ & $20.36 \pm 5.67$ & $20.83 \pm 6.25$ & 0.664 \\
\hline \multicolumn{4}{|c|}{ Periodontal conditions (4 years follow-up) } \\
\hline $\begin{array}{r}\text { Sites with } P D \geq \\
4 \mathrm{~mm}\end{array}$ & $7.11 \pm 12.08$ & $7.16 \pm 8.10$ & 0.980 \\
\hline $\begin{array}{r}\text { Sites with } P D \geq \\
6 \mathrm{~mm}\end{array}$ & $0.89 \pm 0.30$ & $0.87 \pm 1.23$ & 0.969 \\
\hline $\begin{array}{r}\text { Sites with } \mathrm{PD} \geq 4 \\
\mathrm{~mm} \text { concomitant } \\
\text { BOP }\end{array}$ & $0.36 \pm 0.48$ & $0.43 \pm 0.50$ & 0.442 \\
\hline $\begin{array}{r}\text { Sites with } \mathrm{PD} \geq 6 \\
\mathrm{~mm} \text { concomitant } \\
\text { BOP }\end{array}$ & $0.21 \pm 0.85$ & $0.22 \pm 0.55$ & 0.913 \\
\hline $\begin{array}{l}\text { Number of } \\
\text { present teeth }\end{array}$ & $19.09 \pm 6.56$ & $19.02 \pm 6.68$ & 0.950 \\
\hline \multicolumn{4}{|c|}{ Periodontal conditions (alteration) } \\
\hline $\begin{array}{r}\text { Sites with } P D \geq \\
4 \mathrm{~mm}\end{array}$ & $-2.79 \pm 11.02$ & $-8.45 \pm 12.44$ & 0.000 \\
\hline $\begin{array}{r}\text { Sites with } P D \geq \\
6 \mathrm{~mm}\end{array}$ & $-0.79 \pm 4.06$ & $-1.87 \pm 4.72$ & 0.170 \\
\hline $\begin{array}{r}\text { Sites with } \mathrm{PD} \geq 4 \\
\mathrm{~mm} \text { concomitant } \\
\text { BOP }\end{array}$ & $-1.15 \pm 4.98$ & $-4.27 \pm 7.34$ & 0.004 \\
\hline $\begin{array}{r}\text { Sites with } \mathrm{PD} \geq 6 \\
\mathrm{~mm} \text { concomitant } \\
\text { BOP }\end{array}$ & $-0.39 \pm 1.86$ & $-0.79 \pm 1.97$ & 0.250 \\
\hline $\begin{array}{l}\text { Number of } \\
\text { present teeth }\end{array}$ & $1.10 \pm 2.17$ & $1.62 \pm 2.60$ & 0.224 \\
\hline
\end{tabular}

Data expressed as mean \pm standard deviation

$\mathrm{HbA} 1 \mathrm{c}=$ glycated hemoglobin, $\mathrm{PD}=$ probing pocket depth, $\mathrm{BOP}=$ bleeding on probing

t test was used to analysed

individuals, respectively. When we compared the groups, there were no statistically significant differences between groups in participants who received scaling or those who received scaling with root planning $(\mathrm{p}=$ 0.862 and $p=0.894$, respectively).

\section{Discussion}

To our knowledge, this is the first longitudinal observational study to compare the potential of low and high serum resistin level at baseline to predict the periodontal condition alteration of communitydwelling elderly in a 4-year period. The primary outcome variable was the association between the baseline serum resistin level and the alteration 
I Table 3. Multiple linear regression analysis and associated $p$-value using change in sites with $\mathrm{PD} \geq 4 \mathrm{~mm}$ as a dependent variable

\begin{tabular}{|c|c|c|c|c|c|}
\hline \multirow{2}{*}{$\begin{array}{l}\text { Independent } \\
\text { variables }\end{array}$} & \multicolumn{5}{|c|}{$\begin{array}{l}\text { Dependent variable: changes in sites with } P D \geq 4 \\
\text { mm }\end{array}$} \\
\hline & Coefficient & S.E. & $\mathbf{t}$ & $95 \% \mathrm{Cl}$ & $p$-value \\
\hline $\begin{array}{l}\text { Resisitin } \\
(\mathrm{ng} / \mathrm{mL})\end{array}$ & -0.49 & 0.28 & -1.76 & $-1.05-0.06$ & 0.080 \\
\hline $\begin{array}{r}\text { Adiponectin } \\
(\mu \mathrm{g} / \mathrm{mL})\end{array}$ & -0.01 & 0.19 & -0.04 & $-0.38-0.36$ & 0.967 \\
\hline $\begin{array}{r}\text { TNF-a (pg/ } \\
\mathrm{mL})\end{array}$ & 0.39 & 0.56 & 0.70 & $-0.72-1.52$ & 0.487 \\
\hline IL-6 (pg/mL) & -0.05 & 0.48 & 0.11 & $-0.90-1.00$ & 0.915 \\
\hline $\begin{array}{l}\text { Number of } \\
\text { tooth loss }\end{array}$ & -2.48 & 0.39 & -6.23 & $-3.27-1.69$ & 0.000 \\
\hline Constant & 0.70 & 2.93 & 0.24 & $-5.09-6.51$ & 0.240 \\
\hline
\end{tabular}

$\mathrm{R}$-square $=0.281, \mathrm{PD}=$ probing pocket depth, $\mathrm{S} . \mathrm{E}$. $=$ standard error, $\mathrm{t}=\mathrm{t}$ test statistic $\mathrm{Cl}=$ confidence interval, TNF- $\mathrm{a}=$ tumor necrosis factor alpha, $\mathrm{LL}-6=$ interleukin- 6

Table 4. Multiple linear regression analysis and associated $p$-value using change in sites with $\mathrm{PD} \geq 4 \mathrm{~mm}$ concomitant $\mathrm{BOP}$ as a dependent variable

\begin{tabular}{|c|c|c|c|c|c|}
\hline \multirow{2}{*}{$\begin{array}{r}\text { Independent } \\
\text { variables }\end{array}$} & \multicolumn{5}{|c|}{$\begin{array}{l}\text { Dependent variable: changes in sites with } \mathrm{PD} \geq \mathbf{4} \\
\text { mm, concomitant BOP }\end{array}$} \\
\hline & Coefficient & S.E. & $\mathbf{t}$ & $95 \% \mathrm{Cl}$ & $p$-value \\
\hline $\begin{array}{l}\text { Resisitin } \\
\text { (ng/mL) }\end{array}$ & -0.41 & 0.15 & -2.66 & $-0.72-0.10$ & 0.009 \\
\hline $\begin{array}{r}\text { Adiponectin } \\
(\mu \mathrm{g} / \mathrm{mL})\end{array}$ & -0.02 & 0.10 & -0.28 & $-0.23-0.17$ & 0.777 \\
\hline $\begin{array}{r}\text { TNF- } \alpha(p g / \\
\mathrm{mL})\end{array}$ & 0.31 & 0.31 & 0.99 & $-0.30-0.93$ & 0.323 \\
\hline IL-6 (pg/mL) & -0.01 & 0.26 & -0.07 & $-0.54-0.50$ & 0.945 \\
\hline $\begin{array}{l}\text { Number of } \\
\text { tooth loss }\end{array}$ & -0.78 & 0.21 & -3.55 & $-1.21--0.34$ & 0.001 \\
\hline Constant & 1.00 & 1.61 & 0.62 & $-2.19-4.20$ & 0.536 \\
\hline
\end{tabular}

$\mathrm{R}$-square $=0.281, \mathrm{PD}=$ probing pocket depth, $\mathrm{S} . \mathrm{E}$. $=$ standard error, $\mathrm{t}=\mathrm{t}$ test statistic $\mathrm{Cl}=$ confidence interval, TNF- $\mathrm{a}=$ tumor necrosis factor alpha, $\mathrm{lL}-6=$ interleukin- 6

I Table 5. Comparison of number and percentages of participants who received periodontal treatment between low and high serum resistin group during study period

\begin{tabular}{|c|c|c|c|}
\hline \multirow{2}{*}{$\begin{array}{r}\text { Type of } \\
\text { periodontal } \\
\text { treatment } \\
\text { received }\end{array}$} & \multicolumn{2}{|c|}{ Resistin } & \multirow[b]{2}{*}{$p$ value } \\
\hline & $\begin{array}{r}\mathrm{LR}(<5.3 \mathrm{ng} / \\
\mathrm{mL}) \mathrm{N}=84\end{array}$ & $\begin{array}{r}\mathrm{HR}(\geq 5.3 \mathrm{ng} / \\
\mathrm{mL}) \mathrm{N}=48\end{array}$ & \\
\hline Scaling only (\%) & $69(82.14)$ & $40(83.33)$ & 0.862 \\
\hline $\begin{array}{l}\text { Scaling and root } \\
\text { planing (\%) }\end{array}$ & $36(42.86)$ & $20(41.67)$ & 0.894 \\
\hline
\end{tabular}

of inflammatory-related periodontal parameters. We demonstrated that the high serum resistin levels seemed more sensitive to contribute to the other factors-mediated improved periodontal condition more than those in the low resistin counterpart. The association between the other serological parameters at baseline as well as the number of teeth lost in 4 years, and the alteration of the periodontal condition were the secondary outcome variables.

The participants in the present study were in a relatively good periodontal condition (at baseline average sites with $\mathrm{PD} \geq 4 \mathrm{~mm}$, and those concomitant BOP were 11.99 sites and 3.88 sites, respectively). Basically, periodontal disease activity can be measured by many parameters such as probing pocket depth, clinical attachment level, radiographic bone level, and bleeding on probing. Among these parameters, bleeding on probing is a reliable indicator that can be used to monitor periodontal disease activity in clinical situation [26], especially when focusing on inflammation as a primary outcome. This is the reason why we emphasized the analysis of the sites with periodontal pocket depth $\geq 4 \mathrm{~mm}$ concomitant BOP in our study. Our results indicated that the periodontal disease activity in our participants were much lower than in the previous report [20].

Two meta-analyses $[27,28]$ have demonstrated that individuals who were obese or had high body mass index (BMI) seemed susceptible to periodontitis more than normal weight individuals. And the high resistin levels were observed in obese individuals with periodontitis. The participants in the precedent study had normal BMI, but in individuals with relatively high BMl or the obese ones we did not observe this tendency suggesting that obesity modulates resistin independent of periodontitis.

A previous cross-sectional study by Furugen et al. [9] indicated that serum resistin levels were significantly correlated with BOP, and leukocyte counts, but weakly correlated with average PD. The present study also similarly found a significant correlation of sites with $P D \geq 4 \mathrm{~mm}$ as well as sites with $\mathrm{PD} \geq 4 \mathrm{~mm}$ concomitant $\mathrm{BOP}$ at baseline with serum resistin level. These results support the previous report that resistin play an importantroleininflammation[12].Butsinceall previous studies were cross-sectional studies; causality-effect relationship could not be obtained. It is noteworthy that for long term association of serum resistin level and periodontal parameters, high serum resistin level at baseline appeared to influence more profoundly the effect of the periodontal condition alteration. The possible explanation of these findings is based on the fact that all participants were aware of their periodontal condition mainly because they were subjected to periodontal examination and oral hygiene instruction. These led most of the participants to receive extensive periodontal treatment by themselves elsewhere over the period of the present study. However, the percentages of participants who received periodontal treatment in both groups are almost the same (Table 5). Nonetheless, the periodontal conditions of the high resistin group remained more improved than the low resistin group. These results were probably due to resistin significantly correlated only to severe systemic inflammation condition such as in angina patient [29], but in case of mild or localized inflammation such as stable angina and mild periodontitis, which is not severe enough to sense signaling to activate resistin, resulting in almost no positive relationship between the serum resistin level and the periodontal condition $[14,19,30]$. Our results were somehow different from these studies because we demonstrated the inverse association between serum resistin level and long-term periodontitis progression in a fashion that the higher the serum resistin levels the better the sensitivity to periodontal treatment effectiveness. Moreover, resistin plays a role not only in the peripheral area, but it also functions in a central nervous system. It was found that resistin inhibits dopamine and norepinerphrine in rat hypothalamus [31]. Furthermore, an increase in 
serum resistin levels is related to the inhibition of the parasympathetic nervous system [32]. To date, there is still a lack of promising data in humans. This is because there is a striking difference in terms of biological responses between humans and rodents. Hence, we postulated that high serum resistin at baseline in our subjects might be a signaling factor to activate the central nervous system regulating an extensive amelioration of the local inflammation. In contrast, a low serum resistin level might not provide an adequate signal to stimulate the reduction of the peripheral inflammation. The exact mechanism to explain this finding, however, has not yet been fully elucidate. Furthermore, resistin may respond differently depending on the age of the patients because it was found that resistin levels in children had no correlation with metabolic parameters. However, they correlated only with the onset of pubertal development [33]. Thus, resistin in the elderly probably exerts different effects than in the adults. Additionally, the serum resistin level is also affected by many other factors such as lipopolysaccharides form oral pathogens [13], insulin level [10,34], cardiovascular disease condition [35], and chronic kidney disease [36]. All these factors might exert an effect on serum resistin levels more than local inflammation occurring in mild/moderate periodontitis. Conversely to the effect of serum resistin on the alteration of the periodontal condition, serum IL-6 and adiponectin level were hardly associated with the change of the periodontal condition (data not shown). For IL-6, the results are somewhat supported by the previous reports [37-39] in which these molecules were produced mainly only during the early inflammation event and were probably synthesized only in low level in elderly. Therefore, in the long-term observation and with a relatively low level of localized inflammation such as in the present study, we could not observe any effect of IL-6 on the periodontal condition changes. For adiponectin, previous studies suggested that periodontal treatment had minimally influenced the serum adiponectin level [9,39-42]. The present study added up this relationship, in which serum adiponectin level was relatively minimally influenced by the alteration of the periodontal condition. Indeed, adiponectin is said to be an antiinflammatory molecule that can be impaired by resistin [43]. Regarding TNF- $a$, we demonstrated that the TNF-a level at baseline slightly positively affected periodontal disease progression (regression coefficient of 0.39 and 0.31 for change of sites with $P D \geq 4 \mathrm{~mm}$, and sites with $\mathrm{PD} \geq 4 \mathrm{~mm}$ concomitant BOP, respectively). TNF-a is a well-recognized cytokine related to the inflammatory process, and this molecule could be secreted by adipocytes [44], and immune cells [45]. Some studies have shown the positive association between serum TNF- $a$ and periodontitis $[46,47]$. Our study is in line with these studies and contributes to the establishment of the role of the TNF-a in inflammatory enhancement. Regarding the number of tooth loss which had a strong association with the reduction of the sites with $P D \geq 4$ $\mathrm{mm}$ in 4 years, it is a common phenomenon that teeth which had been diagnosed on the basis of periodontal etiology/criteria, as having a poor prognosis in the elderly, on the basis of periodontal etiology/criteria, were the main sources of multiple, and relatively deep periodontal pockets. Based on theoretical and clinical knowledge such teeth would be extracted. The data of the present study showed that approximately $5.1-7.8 \%$ of teeth were lost during the 4 years in LR and HR group, respectively. This was considered an important factor that dramatically reduced the sites with $\mathrm{PD} \geq 4 \mathrm{~mm}$ and these sites $\mathrm{PO} \geq$ 4 concomitant BOP, which collectively improved the periodontal condition as shown in the study population.

Additionally, it is useful to include other age groups, the leukocyte related parameters e.g. leukocyte count, and genetic information to clarify the general resistin function. Especially from a genetic point of view, although there is no clear association, some Finnish [48] and Japanese [49] study subjects suggested that single nucleotides polymorphism (SNP) in the promoter region of the resistin gene (RETN -420C>G, rs1862513) associated with obesity and diabetes, which may be a link to the increase of the inflammatory reaction. Based on the fact that all participants were non-diabetic and almost classified into normal BMI individuals, the majority of our subjects probably might not have this SNP locus.

The present study has some limitations that should be carefully taken into consideration when interpreting the results. First, because of the observational nature of our study, we could not discourage individuals from receiving periodontal treatment, thus improving of individual periodontal condition. This might have in part contributed to the observed effect of the periodontal treatment they received. Furthermore, as aforementioned almost all participants were relatively in a good periodontal condition from the beginning of the study, therefore detecting the association between severe periodontitis and the serum resistin level could not be achieved. Finally, we had no data on the serum resistin level as well as the other serological parameters at the follow-up period to re-evaluate the relationship of serum resistin level and other adipokines/cytokines, and periodontal condition in a low inflammatory state. Monitoring the level of adipokines/cytokines at the end of study should be included in the future studies.

\section{Conclusion}

The present results provide evidence that high serum resistin levels are associated with a dramatic improvement in the long-term periodontal condition especially when considering bleeding on probing in the Japanese elderly. There was also a finding that resistin plays an important role in inflammation.

\section{Author contributions}

Conceptualization: HO. Methodology: $\mathrm{HO}$ and TD. Investigation: $\mathrm{HO}, \mathrm{RF}$ and $\mathrm{HH}$. Writing: $\mathrm{HO}$ and TD. Funding: TS and HM. Resources: AY.

\section{Acknowledgement}

We would like to thank all study participants for their kind co-operation. This study was supported by Grantin-Aids from the Japan Society for the Promotion of Science (09470469) from the Ministry of Education, Culture, Sports, Science and Technology of Japan.

The author declares no conflict of interest related to this 
study. There are no conflicts of interest and no financial interests to be disclosed.

\section{References}

1. Fantuzzi G. Adipose tissue, adipokines, and inflammation. J Allergy Clin Immunol. 2005;115(5):911-919; quiz 920. doi:10.1016/j.jaci.2005.02.023.

[Full text links] [PubMed] Google Scholar (2309) Scopus (1409)

2. Procaccini C, De Rosa V, Galgani $M$, et al. Role of adipokines signaling in the modulation of T cells function. Front Immunol. 2013;4:332. doi:10.3389/fimmu.2013.00332. Review. [Full text links] [Free PMC Article] [PubMed] Google Scholar (53) Scopus (37)

3. Bulló M, García-Lorda P, Megias I, Salas-Salvadó J. Systemic inflammation, adipose tissue tumor necrosis factor, and leptin expression. Obes Res. 2003;11(4):525-531. doi:10.1038/oby.2003.74 [Full text links] [Free Article] [PubMed] Google Scholar (403) Scopus (248)

4. Kern PA, Saghizadeh M, Ong JM, et al. The expression of tumor necrosis factor in human adipose tissue. Regulation by obesity, weight loss, and relationship to lipoprotein lipase. J Clin Invest. 1995;95(5):2111-2119. doi:10.1172/jci117899.

[Full text links] [Free PMC Article] [PubMed] Google Scholar (1461) Scopus (997)

5. Hotamisligil GS, Spiegelman BM. Tumor necrosis factor alpha: a key component of the obesity-diabetes link. Diabetes. 1994:43(11):1271-1278.

[Full text links] [PubMed] Google Scholar (1591) Scopus (1054)

6. Wellen KE, Hotamisligil GS. Inflammation, stress, and diabetes. J Clin Invest. 2005;115(5):1111-1119. doi:10.1172/jci25102. [Full text links] [Free PMC Article] [PubMed]Google Scholar (3673)Scopus (2242)

7. Ouchi N, Kihara S, Arita Y, et al. Novel modulator for endothelial adhesion molecules: adipocyte-derived plasma protein adiponectin. Circulation. 1999;100(25): 2473-2476.

[Full text links] [PubMed] Google Scholar (2789) Scopus (1743)

8. Wolf $A M$, Wolf $D$, Rumpold $H$, et al. Adiponectin induces the anti-inflammatory cytokines IL-10 and IL-1RA in human leukocytes. Biochem Biophys Res Commun. 2004;323(2):630635. doi:10.1016/j.bbrc.2004.08.145

[Full text links] [PubMed] Google Scholar (714) Scopus (474)

9. Furugen $\mathrm{R}$, Hayashida $\mathrm{H}$, Yamaguchi $\mathrm{N}$, et al. The relationship between periodontal condition and serum levels of resistin and adiponectin in elderly Japanese. J Periodontal Res. 2008;43(5):556-562. doi:10.1111/j.1600-0765.2008.01085.x [Full text links][PubMed]Google Scholar (74)Scopus (46)

10. Steppan CM, Bailey ST, Bhat S, et al. The hormone resistin links obesity to diabetes. Nature. 2001;409(6618):307-312. doi:10.1038/35053000

[Full text links] [PubMed] Google Scholar (5646) Scopus (3282)

11. Rea R, Donnelly R. Resistin: an adipocyte-derived hormone Has it a role in diabetes and obesity? Diabetes Obes Metab. 2004;6(3):163-170. doi:10.1111/j.1462-8902.2004.00334.x. [Full text links] [PubMed] Google Scholar (122)

12. Holcomb IN, Kabakoff RC, Chan B, et al. FIZZ1, a novel cysteinerich secreted protein associated with pulmonary inflammation, defines a new gene family. EMBO J. 2000;19(15):4046-4055 doi:10.1093/emboj/19.15.4046.

[Full text links] [Free PMC Article] [PubMed] Google Scholar (763) Scopus (521)

13. Lehrke M, Reilly MP, Millington SC, et al. An inflammatory cascade leading to hyperresistinemia in humans. PLoS Med. 2004;1(2):e45. doi:10.1371/journal.pmed.0010045.

[Full text links] [Free PMC Article] [PubMed] Google Scholar (560) Scopus (360)

14. Bokarewa M, Nagaev I, Dahlberg L, et al. Resistin, an adipokine with potent proinflammatory properties. J Immunol. 2005;174(9):5789-5795. doi: https://doi.org/10.4049/ jimmunol.174.9.5789.

[Full text links] [PubMed] Google Scholar (875) Scopus (591)

15. Rea R, Donnelly R. Effects of metformin and oleic acid on adipocyte expression of resistin. Diabetes Obes Metab. 2006;8(1):105-109. doi:10.1111/j.1463-1326.2005.00477.x. [Full text links] [PubMed] Google Scholar (18) Scopus (14)

16. Ohlrich EJ, Cullinan MP, Seymour GJ. The immunopathogenesis of periodontal disease. Aust Dent J. 2009;54 Suppl 1:S2-10. doi: 10.1111/j.1834-7819.2009.01139.x.

[Full text links] [PubMed] Google Scholar (153) Scopus (64)

17. Kinane DF, Lappin DF. Immune processes in periodontal disease: a review. Ann Periodontol. 2002;7(1):62-71. doi:10.1902/ annals.2002.7.1.62. Review.

[PubMed] Google Scholar (100) Scopus (53)

18. Saito T, Shimazaki Y, Sakamoto M. Obesity and periodontitis. N Engl J Med. 1998;339(7):482-483. doi:10.1056/ nejm199808133390717.

[Full text links] [PubMed] Google Scholar (266) Scopus (140)
19. Devanoorkar A, Dwarakanath CD, Gundanavar G, et al. Evaluation of serum resistin levels in periodontal health and disease and effects of non surgical periodontal therapy on its levels. Dis Markers. 2012;32(5):289-294. doi: 10.3233/DMA-2012-0891. [Full text links] [Free PMC Article] [PubMed] Google Scholar (23) Scopus (9)

20. Rahardjo A, Yoshihara A, Amarasena N, et al. Relationship between bleeding on probing and periodontal disease progression in community-dwelling older adults. J Clin Periodontol. 2005;32(11):1129-1133. doi:10.1111/j.1600-051X.2005.00834.X. [Full text links] [PubMed] Google Scholar (10) Scopus (10)

21. Devanoorkar A, Kathariya R, Guttiganur N, et al. Resistin: a potential biomarker for periodontitis influenced diabetes mellitus and diabetes induced periodontitis. Dis Markers. 2014; 2014:930206. doi: 10.1155/2014/930206.

[Full text links] [Free PMC Article] [PubMed] Google Scholar (26) Scopus (12)

22. Ogawa H, Damrongrungruang T, Hori S, et al. Effect of periodontal treatment on adipokines in type 2 diabetes. World J Diabetes. 2014:5(6):924-931. doi: 10.4239/wjd.v5.i6.924. [Full text links] [Free PMC Article] [PubMed] Google Scholar (13)

23. Armitage GC. Development of a classification system for periodontal diseases and conditions. Ann Periodontol. 1999;4(1):1-6. doi:10.1902/annals.1999.4.1.1. [PubMed] Google Scholar (4387) Scopus (50)

24. Kuzuya T, Nakagawa S, Satoh J, et al. [Report of the Committee of Japan Diabetes Society on the classification and diagnostic criteria of diabetes mellitus]. Japanese. Journal of Japanese Diabetic Society. 1999;42(5):385-404. doi.org/10.11213/ tonyobyo1958.42.385.

[Full text links] [PubMed] Google Scholar (736) Scopus (446)

25. WHO expert consultation. Appropriate body-mass index for Asian populations and its implications for policy and intervention strategies. Lancet. 2004;363(9403):157-163. doi: 10.1016/s0140-6736(03)15268-3.

[Full text links] [PubMed] Google Scholar (4595) Scopus (3993)

26. Joss A, Adler R, Lang NP. Bleeding on probing. A parameter for monitoring periodontal conditions in clinical practice. J Clin Periodontol. 1994;21(6):402-408. doi: 10.1111/j.1600-051X.1994. tb00737.x

[Full text links] [PubMed] Google Scholar (225) Scopus (116)

27. Chaffee BW, Weston SJ. Association between chronic periodonta disease and obesity: a systematic review and meta-analysis. Periodontol. 2010;81(12):1708-1724. doi: 10.1902/jop.2010.100321. [Full text links] [Free PMC Article] [PubMed] Google Scholar (321) Scopus (179)

28. Suvan J, D'Aiuto F, Moles DR, Petrie A, Donos N. Association between overweight/obesity and periodontitis in adults. A systematic review. Obes Rev. 2011;12(5):e381-404. doi: 10.1111/j.1467-789X.2010.00808.x. [Full text links] [PubMed] Google Scholar (260) Scopus (157)

29. Hu WL, Qiao SB, Hou Q, Yuan JS. Plasma resistin is increased in patients with unstable angina. Chin Med J (Engl). 2007;120(10):871-875. doi: 10.1111/j.1476-5381.2011.01369.x. [PubMed] Google Scholar (66) Scopus (36)

30. Davies RC, Jaedicke KM, Barksby HE, et al. Do patients with aggressive periodontitis have evidence of diabetes? A pilot study. J Periodontal Res. 2011;46(6):663-672. doi: 10.1111/j.1600 0765.2011.01388.x

[Full text links] [PubMed] Google Scholar (13)

31. Brunetti L, Orlando G, Recinella L, et al. Resistin, but not adiponectin, inhibits dopamine and norepinephrine release in the hypothalamus. Eur J Pharmacol. 2004;493(1-3):41-44. doi:10.1016/j.ejphar.2004.04.020. Google Scholar (64) Scopus (47)

32. Piestrzeniewicz $K$, Luczak K, Lelonek $M$, et al. Obesity and heart rate variability in men with myocardial infarction. Cardiol J. 2008;15(1):43-49.

[Full text links] [PubMed] Google Scholar (56) Scopus (39)

33. Gerber M, Boettner A, Seidel B, et al Serum resistin levels of obese and lean children and adolescents: biochemical analysis and clinical relevance. J Clin Endocrinol Metab. 2005;90(8): 45034509. doi:10.1210/jc.2005-0437. [Full text links] [PubMed] Google Scholar (184) Scopus (134)

34. Duman BS, Cagatay P, Hatemi H, Ozturk M. Association of Resistin Gene 3'-Untranslated Region EX4-44G-->A Polymorphism with Obesity- and Insulin-Related Phenotypes in Turkish Type 2 Diabetes Patients. Rev Diabet Stud. 2007; 4: 49-55. [Full text links] [Free PMC Article] [PubMed] Google Scholar (8)

35. Takeishi Y, Niizeki T, Arimoto T, et al. Serum resistin is associated with high risk in patients with congestive heart failure--a novel link between metabolic signals and heart failure. Circ J. 2007; 71: 460-464. doi.org/10.1253/circj.71.460. [Full text links] [PubMed] Google Scholar (87) Scopus (63)

36. Yaturu S, Reddy RD, Rains J, Jain SK. Plasma and urine levels of resistin and adiponectin in chronic kidney disease. Cytok [Full text links] [PubMed] Google Scholar (66) Scopus (39)

37. Genco RJ, Grossi SG, Ho A, et al. A proposed model linking inflammation to obesity, diabetes, and periodontal 
infections. J Periodontol. 2005; 76: 2075-2084. doi:10.1902/ jop.2005.76.11-S.2075.

[Full text links] [PubMed] Google Scholar (574) Scopus (311)

38. Saxlin T, Suominen-Taipale L, Leiviska J, et al. Role of serum cytokines tumour necrosis factor-alpha and interleukin-6 in the association between body weight and periodontal infection. J Clin Periodontol. 2009; 36: 100-105. doi:10.1111/j.1600-051X.2008.01350.x.

[Full text links] [PubMed] Google Scholar (41) Scopus (17)

39. Jaedicke K, Preshaw P, Taylor J. Salivary cytokines as biomarkers of periodontal diseases. Periodontology 2000. 2016; 70: 164-183. doi: $10.1111 /$ prd.12117.

[Full text links] [PubMed] Google Scholar (25)

40. Iwamoto Y, Nishimura F, Soga Y, et al. Antimicrobial periodontal treatment decreases serum C-reactive protein, tumor necrosis factor-alpha, but not adiponectin levels in patients with chronic periodontitis. J Periodontol. 2003; 74: 1231-1236. doi:10.1902/ jop.2003.74.8.1231.

Google Scholar (192) Scopus (113)

41. Bharti P, Katagiri S, Nitta H, et al. Periodontal treatment with topical antibiotics improves glycemic control in association with elevated serum adiponectin in patients with type 2 diabetes mellitus. Obes Res Clin Pract. 2013; 7: e129-e138. doi: 10.1016/j.orcp.2011.11.005. [PubMed] Google Scholar (30) Scopus (15)

42. Gonçalves TE, Zimmermann GS, Fiqueiredo LC, et al. Local and serum levels of adipokines in patients with obesity afte periodontal therapy: one-year follow-up. J Clin Periodontol. 2015; 42: 431-439. doi: 10.1111/jcpe.12396.

[Full text links] [PubMed] Google Scholar (23) Scopus (14)

43. Kawanami D, Maemura K, Takeda N, et al. Direct reciprocal effects of resistin and adiponectin on vascular endothelial cells: a new insight into adipocytokine-endothelial cell interactions. Biochem Biophys Res Commun. 2004; 314: 415-419.
[Full text links] [PubMed] Google Scholar (553) Scopus (330)

44. Tsigos C, Kyrou I, Chala E, et al. Circulating tumor necrosis factor alpha concentrations are higher in abdominal versus peripheral obesity. Metabolism. 1999; 48: 1332-1335.

[Full text links] [PubMed] Google Scholar (229) Scopus (164)

45. Preshaw PM, Taylor JJ. How has research into cytokine interactions and their role in driving immune responses impacted our understanding of periodontitis? J Clin Periodontol. 2011; 38 Suppl 11:60-84. doi:10.1111/j.1600-051X.2010.01671.x. [Full text links] [PubMed] Google Scholar (283)

46. Graves DT, Cochran D. The contribution of interleukin-1 and tumor necrosis factor to periodontal tissue destruction. J Periodontol. 2003; 74: 391-401. doi:10.1902/jop.2003.74.3.391. [Full text links] [PubMed] Google Scholar (805) Scopus (459)

47. Passoja A, Puijola I, Knuuttila M, et al. Serum levels of interleukin-10 and tumour necrosis factor-alpha in chronic periodontitis. J Clin Periodontol. 2010; 37: 881-887. doi:10.1111/ j.1600-051X.2010.01602.x.

[Full text links] [PubMed] Google Scholar (70) Scopus (2)

48. Conneely KN, Silander $\mathrm{K}$ Scott $\mathrm{L}$, et al Variation in the resistin gene is associated with obesity and insulin-related phenotypes in Finnish subjects. Diabetologia. 2004; 47: 1782-1788. doi:10.1007/s00125-004-1537-x.

[Full text links] [Free PMC Article] [PubMed] Google Scholar (98) Scopus (69)

49. Osawa $\mathrm{H}$, Yamada $\mathrm{K}$, Onuma $\mathrm{H}$, et al. The $\mathrm{G} / \mathrm{G}$ genotype of a resistin single-nucleotide polymorphism at -420 increases type 2 diabetes mellitus susceptibility by inducing promoter activity through specific binding of Sp1/3. Am J Hum Genet. 2004;75(4):678-686. doi:10.1086/424761.

[Full text links] [Free PMC Article] [PubMed] Google Scholar (202) Scopus (161)

\section{Hiroshi OGAWA \\ DDS, MDSc, PhD, Associate Professor Division of Preventive Dentistry, Department of Oral Health Science Graduate School of Medical and Dental Sciences, Niigata University Niigata, Japan}

Dr Hiroshi Ogawa acquired his dentist qualifications at the Nihon University in Japan in 1994, his Masters in Public Health Dentistry at the University of Sydney in Australia and his PhD in Preventive Dentistry at Niigata University in Japan. He has been Associate Professor at the Graduate School of Medical and Dental Sciences and also Vice-Director of WHO Collaborating Centre for Translation of Oral Health Sciences at Niigata University. For several years he served at the WHO HQ-Geneva as Dental Officer of the Global Oral Health Programme.

His major interest is global oral health promotion in public health perspective and also clinical research to strengthen evidence for the integration of oral and general health.

\section{What is the major inflammatory cytokine shown to overexpress in adipose tissue?}

口a. Adiponectine;

ab. Resistin;

ac. TNF-alpha;

ad. Leptin.

\section{Individuals with impaired fasting glucose and diabetes mellitus,}

$\square$ a. often have degrees of periodontal inflammation;

b. often have degrees of oral carcinoma;

ac. often have degrees of root caries;

$\square$ d. often have degrees of dysphagia.

\section{Periodontal disease could be described as,}

$\square$ a. non-multifactor chronic inflammatory disease;

ab. integrated to immune system;

ac. caused only by intraoral pathogen;

$\square$ d. caused mainly by undernutrition.

\section{Level of adipokine could be influenced by,}

$\square$ a. fluoride gel application;

b. intake of Vitamin supplement;

ac. professional mechanical tooth cleaning;

ad. smoking habit. 